\title{
Chemistry of osmium phenolates. Synthesis, structure and redox properties
}

\author{
Falguni Basuli, ${ }^{a}$ Shie-Ming Peng ${ }^{\mathrm{b}}$ and Samaresh Bhattacharya ${ }^{a}$ \\ "Department of Chemistry, Inorganic Chemistry Section, Jadavpur University, 700032 Calcutta, India

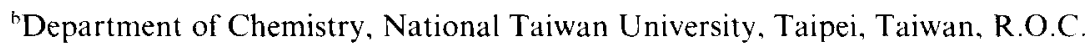

(Received 25 September 1997; accepted 23 January 1998)

\begin{abstract}
The reaction of three phenolic ligands (viz. salicylaldehyde, Hsal; 2-hydroxyacetophenone, Hacp and 2-hydroxynaphthaldehyde, Hnap; generally abbreviated as $\mathrm{HL}$, where $\mathrm{H}$ stands for the phenolic proton) with $\left[\mathrm{Os}(\mathrm{bpy})_{2} \mathrm{Br}_{2}\right]$ has afforded complexes of type $\left[\mathrm{Os}(\mathrm{bpy})_{2}(\mathrm{~L})\right]^{+}$, which have been isolated as the perchlorate salts. The complexes are diamagnetic (low-spin $\mathrm{d}^{6}, \mathrm{~S}=0$ ) and in acetonitrile solution shows several MLCT transitions in the visible region. Structure of the $\left[\mathrm{Os}^{11}(\mathrm{bpy})_{2}(\mathrm{sal})\right] \mathrm{ClO}_{4}$ complex has been determined by X-ray crystallography. The salicylaldehydate anion is coordinated to osmium as a bidentate $\mathrm{O}, \mathrm{O}$-donor and the $\mathrm{OsN}_{4} \mathrm{O}_{2}$ coordination sphere is distorted octahedral. Cyclic voltammetry shows a reversible osmium(II)osmium(III) oxidation in the range of 0.17-0.25 V vs SCE follwed by an irreversible osmium(III)-osmium(IV) oxidation in the range of 1.38-1.48 $\mathrm{V} v s \mathrm{SCE}$. Three one-electron reductions of the coordinated bpy ligands are also observed on the negative side of SCE $(-1.49--2.08 \mathrm{~V})$. Chemical or electrochemical oxidation of the $\left[\mathrm{Os}^{\mathrm{II}}(\mathrm{bpy})_{2}(\mathrm{~L})\right] \mathrm{ClO}_{4}$ complex affords green $\left[\mathrm{Os}{ }^{\mathrm{III}}(\mathrm{bpy})_{2}(\mathrm{~L})\right]^{2+}$ species, which have been isolated as the perchlorate salts. These complexes are one-electron paramagnetic (low-spin $\mathrm{d}^{5}, \mathrm{~S}=1 / 2$ ) and in acetonitrile solution show LMCT transitions in the visible region. Reduction of the green $\left[\mathrm{Os}^{\mathrm{il}}(\mathrm{bpy})_{2}(\mathrm{~L})\right]\left(\mathrm{ClO}_{4}\right)_{2}$ complexes gives back the respective brown $\left[\mathrm{Os}^{\mathrm{Il}}(\mathrm{bpy})_{2}(\mathrm{~L})\right] \mathrm{ClO}_{4}$ complexes. 1998 Elsevier Science $\mathrm{Ltd}$. All rights reserved
\end{abstract}

Ke?'words: osmium; phenolates; synthesis; structure; redox properties.

The chemistry of osmium has been receiving continuous attention [1] largely due to the interesting redox properties exhibited by its complexes. Osmium offers a wide range of chemically accessible oxidation states. The stability and the interconvertibility of these different oxidation states are directed by the coordination environment around the metal ion. Coordination of osmium by ligands of different types is of particular importance in this respect. In the present study, phenolic ligands of type 1 have been used as

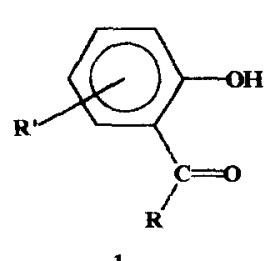

1

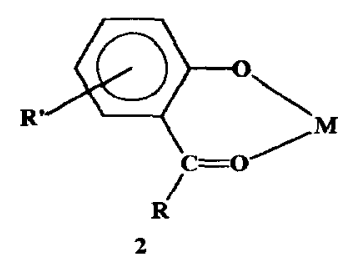

the principal ligand. The ligands are abbreviated in general as HL, where $H$ stands for the dissociable phenolic proton. The phenolate anions ( $\mathrm{L}^{-}$) bind metal ions as bidentate $\mathrm{O}, \mathrm{O}$-coordinator forming six membered chelate ring( 2 ). Coordination by phenolate oxygen is known to be very effective in stabilizing the higher oxidation states of osmium [2]. For example. in the tris-catecholato osmium complex, osmium is in +6 oxidation state, which is stabilized by the six coordinated phenolate oxygens $[2 a, 2 b, 2 e]$. The three phenolic ligands that have been used in the present work are salicylaldehyde (Hsal, 3), 2-hydroxyacetophenone (Hacp, 4) and 2-hydroxynaphthaldehyde (Hnap, 5). It may be noted here that while ruthenium chemistry of these ligands has received considerable attention [3], the analogous osmium chemistry appears to remain unexplored. Herein we have restricted our studies on a group of osmium complexes having only one coordinated L. To satisfy the remaining four coordination sites of osmium in this OsL moiety, 2,2'-bipyridine (bpy) has been used as the 


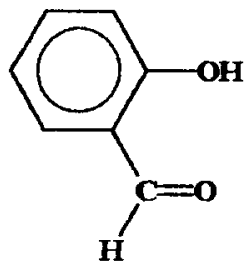

Hsal

3

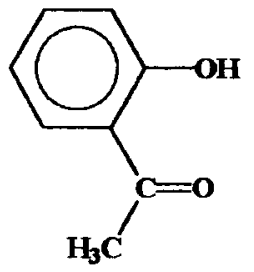

Hacp

4

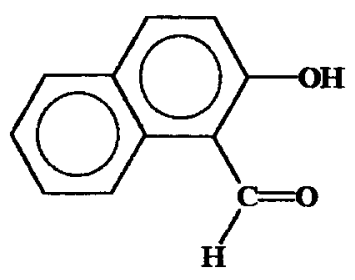

Hnap coligand. The synthesis and characterization of three $\left[\mathrm{Os}(\mathrm{bpy})_{2}(\mathrm{~L}) \mathrm{ClO}_{4}\right.$ complexes and their spectroscopic and electron-transfer properties are reported in this paper.

\section{EXPERIMENTAL}

\section{Materials}

Osmium tetroxide was purchased from Arora Matthey, Calcutta, India and was converted into $\left[\mathrm{NH}_{4}\right]_{2}\left[\mathrm{OsBr}_{6}\right]$ by reduction with $\mathrm{HBr}$ [4]. [Os(bpy $\left.)_{2} \mathrm{Br}_{2}\right]$ was synthesized from $\left[\mathrm{NH}_{4}\right]_{2}\left[\mathrm{OsBr}_{6}\right]$ using a literature method [5]. 2,2'-Bipyridine was purchased from Loba Chemie, Mumbai, India. Salicylaldehyde, 2-hydroxyacetophenone and 2-hydroxynaphthaldehyde were obtained respectively from S.D. (Mumbai), Spectrochem(Mumbai) and Aldrich. All other chemicals and solvents were reagent grade commercial materials and were used as received. Purification of acetonitrile and preparation of tetraethylammonium perchlorate (TEAP) for electrochemical work were performed as reported in the literature $[6,7]$.

\section{Preparation of complexes}

The $\left[\mathrm{Os}^{\mathrm{II}}(\mathrm{bpy})_{2}(\mathrm{~L})\right] \mathrm{ClO}_{4}$ and $\left[\mathrm{Os}^{\mathrm{III}}(\mathrm{bpy})_{2}(\mathrm{~L})\right]\left(\mathrm{ClO}_{4}\right)_{2}$ complexes, reported in this work, were prepared by following two general methods. Specific details are given below for two representative cases.

$\left[\mathrm{Os}^{\mathrm{II}}(\mathrm{bpy})_{2}(\mathrm{sal}) \mathrm{Clo}_{4} \quad\left[\mathrm{Os}(\mathrm{bpy})_{2} \mathrm{Br}_{2}\right] \quad(100 \mathrm{mg}\right.$, $0.15 \mathrm{mmol})$ was taken in 3:1 EtOH-water $\left(40 \mathrm{~cm}^{3}\right)$ and to the solution was added $\mathrm{Hsal}(20 \mathrm{mg}, 0.16 \mathrm{mmol})$ followed by $\mathrm{NEt}_{3}(16 \mathrm{mg}, 0.16 \mathrm{mmol})$. The solution was then heated at reflux for $6 \mathrm{~h}$. After being cooled to room temperature, a saturated solution of $\mathrm{NaClO}_{4}$ $\left(1 \mathrm{~cm}^{3}\right)$ was added to it and the volume of the solution was reduced to about $15 \mathrm{~cm}^{3}$ under reduced pressure. The solution was then kept in the refrigerator for $\sim 24 \mathrm{~h}$. $\left[\mathrm{Os}(\mathrm{bpy})_{2}(\mathrm{sal})\right] \mathrm{ClO}_{4}$ precipitated as a dark brown microcrystalline solid, which was collected by filtration, washed with little ice-cold water and dried in vacuo over $\mathrm{P}_{4} \mathrm{O}_{10}$. Purification of the product was done by recrystallization from dichloromethane-benzene solution. The yield was $85 \mathrm{mg}(78 \%)$.

$\left[\mathrm{Os}^{\mathrm{III}}(\mathrm{bpy})_{2}(\mathrm{sal})\right]\left(\mathrm{Clo}_{4}\right)_{2} \quad\left[\mathrm{Os}{ }^{\mathrm{II}}(\mathrm{bpy})_{2}(\mathrm{sal})\right] \mathrm{ClO}_{4} \quad(100$ $\mathrm{mg}, 0.14 \mathrm{mmol}$ ) was dissolved in acetone $\left(20 \mathrm{~cm}^{3}\right)$ and one drop of bromine was added to it. An instantaneous colour change, from brown to green, took place. The solution was then stirred for $10 \mathrm{~min}$ and a saturated aqueous solution of $\mathrm{NaClO}_{4}\left(0.5 \mathrm{~cm}^{3}\right)$ was added to it. Upon partial evaporation of the solution $\left[\mathrm{Os}(\mathrm{bpy})_{2}(\mathrm{sal})\right]\left(\mathrm{ClO}_{4}\right)_{2}$ precipitated as a green microcrystalline solid, which was collected by filtration, washed with little ice-cold water and dried in vacuo over $\mathrm{P}_{4} \mathrm{O}_{10}$. The yield was $90 \mathrm{mg}(79 \%)$.

\section{Physical measurements}

Microanalyses $(\mathrm{C}, \mathrm{H}, \mathrm{N})$ were performed using a Perkin-Elmer $240 \mathrm{C}$ elemental analyser. Infrared spectra were obtained on a Perkin-Elmer 783 spectrometer with samples prepared as $\mathrm{KBr}$ pellets. Electronic spetra were recorded on a Simadzu UV 1601 spectrophotometer. Magnetic susceptibilities were measured using a PAR 155 vibrating sample magnetometer fitted with a Walker Scientific L75FBAL magnet. 'H NMR spectra were obtained on a Brucker AC-200 NMR spectrometer using TMS as the internal standard. ESR spectra studies were done using a Varian E-109C spectrometer fitted with a quartz Dewar for measurement at $77 \mathrm{~K}$ (liquid nitrogen). Solution electrical conductivities were measured using a Philips PR 9500 bridge with a solute concentration of $10^{-3} \mathrm{M}$. Electrochemical measurements were made using a PAR model 273 potentiostat. A platinum disc or graphite working electrode, a platinum wire auxiliary electrode and an aqueous saturated calomel reference electrode (SCE) were used in a three electrode configuration. A platinum wire gauze working electrode was used in the coulometric experiments. A RE $0074 \mathrm{X}-\mathrm{Y}$ recorder was used to trace the voltammograms. Electrochemical measurements were per- 
Table 1. Crystallographic data for $\left[\mathrm{Os}(\mathrm{bpy})_{2}(\mathrm{sal})\right] \mathrm{ClO}_{4}$. $\mathrm{CH}_{2} \mathrm{Cl}_{2}$

\begin{tabular}{|c|c|}
\hline formula & $\mathrm{C}_{28} \mathrm{H}_{23} \mathrm{~N}_{4} \mathrm{O}_{6} \mathrm{Cl}_{3} \mathrm{O}_{5}$ \\
\hline$f_{w}$ & 807.5 \\
\hline space group & Monoclinic, $\mathrm{P}_{2} / \mathrm{n}$ \\
\hline a, $\mathrm{A}$ & $9.084(2)$ \\
\hline b. A & $20.020(4)$ \\
\hline$c, A$ & $15.998(4)$ \\
\hline$\beta .(1)$ & $92.95(2)$ \\
\hline$V . A=$ & $2905.3(11)$ \\
\hline$Z$ & 4 \\
\hline crystal size. $\mathrm{mm}$ & $0.20 \times 0.25 \times 0.25$ \\
\hline T. K & 298 \\
\hline$\mu . \mathrm{cm}$ & 46.301 \\
\hline $\mathbf{R}_{\mathrm{t}}$ & 0.043 \\
\hline $\mathbf{R}_{\mathrm{w}}$ & 0.039 \\
\hline $\mathrm{GOF}$ & 1.50 \\
\hline
\end{tabular}

$$
\begin{aligned}
& \mathrm{R}_{\mathrm{f}}=\Sigma \| \mathrm{F}_{\mathrm{o}}|-| \mathrm{F}_{\mathrm{c}}|/ \Sigma| \mathrm{F}_{\mathrm{o}} \mid . \\
& \mathrm{R}_{u}=\left[\Sigma w\left(\left|\mathrm{~F}_{0}\right|-\left|\mathrm{F}_{\mathrm{c}}\right|\right)^{2} / \Sigma w\left(\mathrm{~F}_{0}\right)^{2}\right]^{1} .
\end{aligned}
$$

formed under a dinitrogen atmosphere. All electrochemical data were collected at $298 \mathrm{~K}$ and are uncorrected for junction potentials.

\section{Cristallography}

Single crystals of $\left[\mathrm{Os}(\text { bpy })_{2}(\mathrm{sal}) \mathrm{ClO}_{4}\right.$ were grown by slow diffusion of benzene into a dichloromethane solution of the complex. Selected crystal data and data collection parameters are given in Table 1. The unit cell dimensions were determined by a least-squares fit of 25 machine-centered reflections $(15.00<20$ $<21.84$ ). Data were collected on a Enraf-Nonius CAD-4 diffractometer using graphite monochromated $\mathrm{Mo}-\mathrm{K} \alpha$ radiation $(\hat{\lambda}=0.7107 \mathrm{~A})$ by $(0-20$ scans within the angular range 3.045 .0 . Three standard reflections. measured every 3600 seconds of $\mathrm{X}$ ray exposure, showed no significant intensity variation over the course of data collection. X-ray data reduction, and structure solution and refinement were done using the NRCVAX package. The structure was solved by the Patterson method. Final cycles of refinement converged with discrepancy indices of $\mathrm{R}_{\mathrm{f}}=0.043$ and $\mathrm{R}_{\mathrm{u}}=0.039$.

\section{RESULTS AND DISCUSSION}

The three phenolic ligands ( $\mathrm{HL}, 3-5)$ react smoothly with $\left[\mathrm{Os}(\mathrm{bpy})_{2} \mathrm{Br}_{2}\right]$ in 3:1 ethanol-water in the presence of triethylamine to afford complexes of type $\left[\mathrm{Os}(\mathrm{bpy})_{2}(\mathrm{~L})\right]^{+}$, which have been isolated subsequently as the perchlorate salts in the solid state. Some characterization data of the complexes are given in Table 2. Elemental $(\mathrm{C} . \mathrm{H}, \mathrm{N})$ analytical data are in excellent agreement with the compositions of the complexes. 'H NMR spectra of the [Os(bpy), (L)]' complexes have been recorded in $\mathrm{CDCl}_{3}$ solution. The aromatic region of the spectra is rather complex in nature due to overlap of signals and hence assignment of signals in this region to specific protons has not

\begin{tabular}{|c|c|c|c|c|c|c|}
\hline \multirow[t]{2}{*}{ Compound } & \multicolumn{3}{|c|}{ Analytical data } & \multirow{2}{*}{$\begin{array}{c}\Lambda_{\mathrm{M}}^{\mathrm{b}} \\
\Omega^{--1} \mathrm{~cm}^{2} \mathrm{M}^{-1}\end{array}$} & \multirow{2}{*}{$\begin{array}{l}\text { Electronic spectral data } \\
i_{\text {max }}, \mathrm{nm}\left(\left(, \mathrm{M}^{-1} \mathrm{~cm} \quad '\right)\right.\end{array}$} & \multirow{2}{*}{$\begin{array}{l}\text { Cyclic voltammetric data } \\
\text { E. VuSCE }\end{array}$} \\
\hline & $\% \mathrm{C}$ & $\% \mathrm{H}$ & $\% \mathrm{~N}$ & & & \\
\hline$\left[\mathrm{Os}(\text { bpy })_{2}(\mathrm{sal})\right] \mathrm{ClO}_{4}$ & $\begin{array}{c}44.66 \\
(44.84)\end{array}$ & $\begin{array}{c}2.98 \\
(2.90)\end{array}$ & $\begin{array}{c}7.73 \\
(7.75)\end{array}$ & 140 & $\begin{array}{l}746(3800), 585^{d}(5500) \\
500(10600), 431(12000) \\
355^{d}(9200), 297(46800), \\
245(35000), 22 l^{d}(30700) .\end{array}$ & $\begin{array}{l}0.25^{\mathrm{L}}\left(60^{\mathrm{t}}\right), 1.48^{\mathrm{z}} \\
-1.49^{\mathrm{h}},-1.80^{\mathrm{h}} \\
-2.04^{\mathrm{h}}\end{array}$ \\
\hline$\left[\mathrm{Os}(\mathrm{bpy})_{2}(\mathrm{acp})\right] \mathrm{ClO}_{4}$ & $\begin{array}{c}45.57 \\
(45.62)\end{array}$ & $\begin{array}{c}3.15 \\
(3.12)\end{array}$ & $\begin{array}{c}7.62 \\
(7.60)\end{array}$ & 155 & $\begin{array}{l}739(3800), 589^{d}(5900), \\
506(10500), 429(12700), \\
354(9700) .296(45700), \\
246(33600), 215^{\mathrm{d}}(29500) .\end{array}$ & $\begin{array}{l}0.17^{\mathrm{c}}\left(60^{\mathrm{f}}\right), 1.02^{\mathrm{g}} \\
-1.54^{\mathrm{h}},-1.77^{\mathrm{h}} \\
-2.05^{\mathrm{h}}\end{array}$ \\
\hline$\left[\mathrm{Os}(\text { bpy })_{2}\right.$ (nap) $] \mathrm{ClO}_{4}$ & $\begin{array}{c}48.14 \\
(48.15)\end{array}$ & $\begin{array}{c}3.01 \\
(2.98)\end{array}$ & $\begin{array}{c}7.29 \\
(7.25)\end{array}$ & 148 & $\begin{array}{l}677(4800), 584^{\mathrm{d}}(6200) \\
489(13100), 435(14800) \\
362(12300), 296(53400) \\
236^{\mathrm{d}}(37800), 220(57000)\end{array}$ & $\begin{array}{l}0.24^{\circ}\left(60^{\mathrm{f}}\right), 1.48^{\mathrm{b}} \\
-1.52^{\mathrm{h}},-1.78^{\mathrm{h}} \\
-2.08^{\mathrm{h}}\end{array}$ \\
\hline
\end{tabular}

Table 2. Characterization data of the $\left[\mathrm{Os}(\mathrm{bpy})_{2}(\mathrm{~L})\right] \mathrm{ClO}_{4}$ complexes

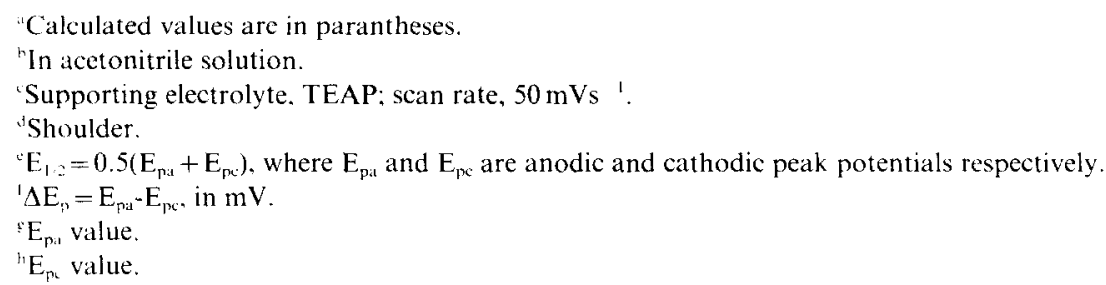


been attempted. However, intensity measurement of these signals corresponds to the total number of aromatic protons present in the respective complexes. In both $\left[\mathrm{Os}(\mathrm{bpy})_{2}(\mathrm{sal})\right]^{+}$and $\left[\mathrm{Os}(\mathrm{bpy})_{2}\right.$ (nap $\left.)\right]^{+}$ complexes, the aldehyde proton of the sal and nap ligands shows a distinct resonance at $9.29 \mathrm{ppm}$. In the $\left[\mathrm{Os}(\mathrm{bpy})_{2}(\mathrm{acp})\right]^{+}$complex, the methyl signal of the acp ligand appears at $2.31 \mathrm{ppm}$.

Molecular structure of $\left[\mathrm{Os}(\mathrm{bpy})_{2}(\mathrm{sal})\right] \mathrm{ClO}_{4}$ has been determined by X-ray crystallography. A view of the molecule is shown in Fig. 1 and selected bond distances and angles are listed in Table 3. The $\mathrm{OsN}_{4} \mathrm{O}_{2}$ coordination sphere is distorted octahedral, which is reflected in the three non-linear trans-angles and the twelve cis-angles (non $90^{\circ}$ ) as well. The salicylaldehyde anion is coordinated to osmium as bidentate $\mathrm{O}, \mathrm{O}$ donor with a bite angle of $91.8(3)$.

Infrared spectra of the $\left[\mathrm{Os}(\mathrm{bpy})_{2}(\mathrm{~L}) \mathrm{ClO}_{4}\right.$ complexes shows many vibrations of different intensities below $1700 \mathrm{~cm}^{-1}$. Comparison of these spectra with the spectrum of $\left[\mathrm{Os}(\mathrm{bpy})_{2} \mathrm{Br}_{2}\right]$ shows that besides the presence of some similar vibrations, which are prob-
Table 3. Selected bond distances and bond angles for $\left[\mathrm{Os}(\mathrm{bpy})_{2}(\mathrm{sal})\right] \mathrm{ClO}_{4} \cdot \mathrm{CH}_{2} \mathrm{Cl}_{2}$

\begin{tabular}{llll} 
& \multicolumn{3}{c}{ Bond Distances $(\AA)$} \\
Os-O1 & $2.033(7)$ & $\mathrm{C} 1-\mathrm{O} 1$ & $1.263(15)$ \\
Os-O2 & $2.052(7)$ & $\mathrm{C} 1-\mathrm{C} 2$ & $1.426(18)$ \\
Os-N1 & $2.035(9)$ & $\mathrm{C} 2-\mathrm{C} 3$ & $1.438(18)$ \\
Os-N2 & $1.979(9)$ & $\mathrm{C} 3-\mathrm{C} 4$ & $1.336(20)$ \\
Os-N3 & $2.021(9)$ & $\mathrm{C} 4-\mathrm{C} 5$ & $1.405(21)$ \\
Os-N4 & $2.042(9)$ & $\mathrm{C} 5-\mathrm{C} 6$ & $1.343(19)$ \\
C6-C7 & $1.416(17)$ & & \\
C7-C2 & $1.412(17)$ & & \\
C7-O2 & $1.290(13)$ & & \\
\multicolumn{5}{c}{ Bond Angles (1) } \\
O1-Os-N2 & $172.9(3)$ & & \\
O2-Os-N3 & $172.6(3)$ & & \\
N1-Os-N4 & $177.1(4)$ & & \\
O1-Os-O2 & $91.8(3)$ & O1-Os-N1 & $94.7(4)$ \\
O1-Os-N3 & $87.5(3)$ & O1-Os-N4 & $86.7(3)$ \\
O2-Os-N1 & $89.2(3)$ & O2-Os-N2 & $85.6(3)$ \\
O2-Os-N4 & $93.3(3)$ & N1-Os-N2 & $78.6(4)$ \\
N1-Os-N3 & $98.2(4)$ & N2-Os-N3 & $95.9(3)$ \\
N2-Os-N4 & $100.1(4)$ & N3-Os-N4 & $79.3(4)$ \\
\hline
\end{tabular}

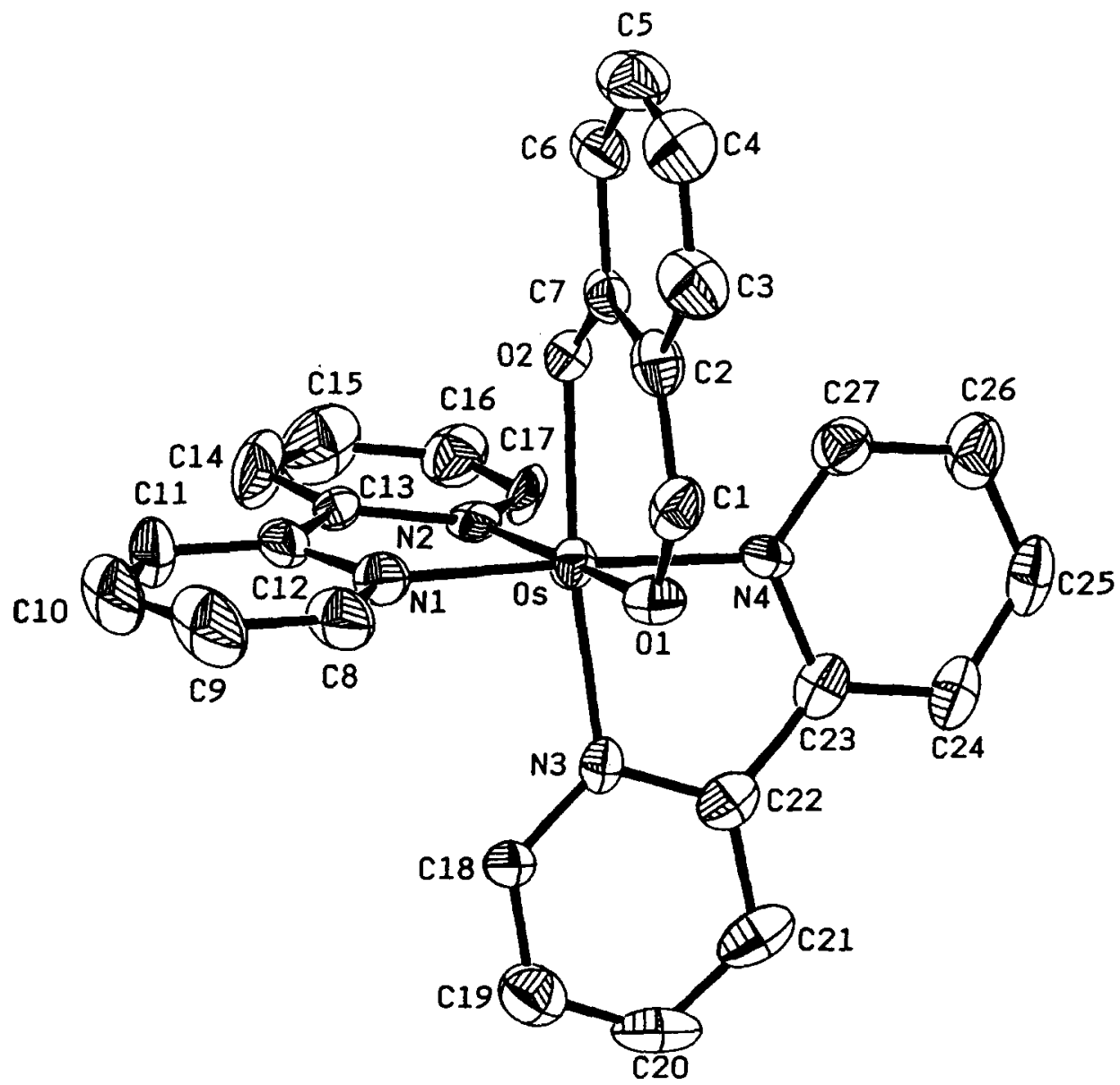

Fig. 1. Structure of $\left[\mathrm{Os}(\mathrm{bpy})_{2}(\mathrm{sal})\right]^{+}$cation. 


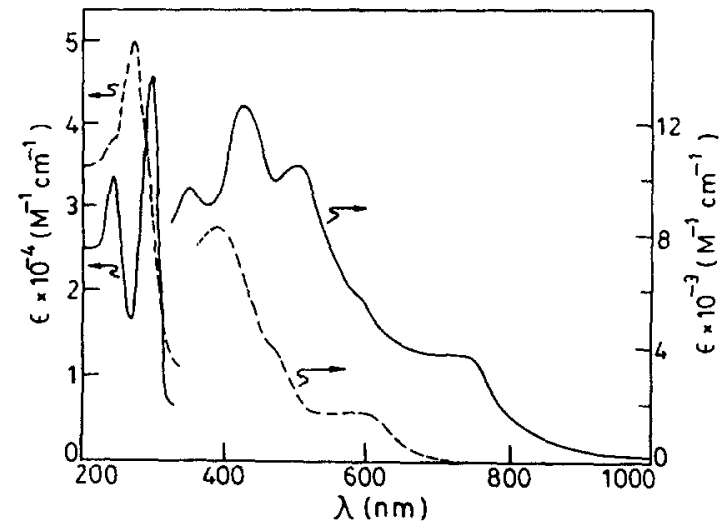

Fig. 2. Electronic spectra of $\left[\mathrm{Os}^{\mathrm{iI}}(\mathrm{bpy})_{2}(\mathrm{acp})\right] \mathrm{ClO}_{4} \cdot(-\cdots$ and $\left[\mathrm{Os}^{\prime \prime \prime}(\mathrm{bpy})_{2}(\mathrm{acp})\right]\left(\mathrm{ClO}_{4}\right)_{2}(---)$ in acetonitrile solution.

ably due to the common Os(bpy) $)_{2}$ moiety, some additional vibrations are observed in the spectra of the $\left[\mathrm{Os}(\text { bpy })_{2}(\mathrm{~L})\right] \mathrm{ClO}_{4}$ complexes. Of these additional vibrations, the two intense ones observed near $1100 \mathrm{~cm}^{-1}$ and $620 \mathrm{~cm}^{-1}$ in all these complexes, are attributed to the perchlorate ion. The other new vibrations are obviously due to the coordinated phenolate ligand $\mathrm{L}$. The $\left[\mathrm{Os}(\mathrm{bpy})_{2}(\mathrm{~L})\right] \mathrm{ClO}_{4}$ complexes are soluble in common polar organic solvents like ethanol. acetone, dichloromethane, acetonitrile etc., producing solutions in different shades of brown. Conductance measurement in acetonitrile solution shows that these complexes behave as 1:1 electrolytes (Table 2), as expected. Electronic spectra of the $\left[\mathrm{Os}(\mathrm{bpy})_{2}(\mathrm{~L}) \mathrm{ClO}_{4}\right.$ complexes have been recorded in acetonitrile solution. Spectral data are presented in Table 2 and a selected spectrum is displayed in Fig. 2. Each complex shows several intense absorptions in the visible region and a few absorptions of very high intensity in the ultraviolet region. The absorptions in the ultraviolet region are attributed to transitions within the ligand orbitals. The intense absorptions in the visible region are probably due to allowed metal-to-ligand charge-transfer transitions. Multiple charge-transfer transitions in these mixed-ligand complexes may result from lower symmetry splitting of the metal level, the presence of different acceptor orbitals and from the mixing of singlet and triplet configurations in the excited state through spin-orbit coupling [8].

\section{CYCLIC VOLTAMMETRIC STUDIES}

Electron-transfer properties of the $\left[\mathrm{Os}(\mathrm{bpy})_{2}(\mathrm{~L})\right]$ $\mathrm{ClO}_{4}$ complexes have been studied in acetonitrile solution ( $0.1 \mathrm{M}$ TEAP) by cyclic voltammetry. All the complexes show two oxidative responses on the positive side of SCE and three reductive responses on the negative side. Voltammetric data are presented in
Table 2 and a selected voltammogram is displayed in Fig. 3.

The first oxidative response exhibited by each complex in the range of $0.17-0.25 \mathrm{~V}$ (all potentials are referenced to SCE) is assigned to the osmium(II)osmium(III) oxidation [eqn. (1)]. This oxidation

$$
\left[\mathrm{Os}(\mathrm{bpy})_{2}(\mathrm{~L})\right]^{+} \leftrightharpoons\left[\mathrm{Os}(\mathrm{bpy})_{2}(\mathbf{L})\right]^{2+}+\mathrm{e}
$$

is reversible, characterized by a peak-to-peak separation $\left(\Delta E_{p}\right)$ of $60 \mathrm{mV}$ which remains unaltered upon changing the scan rate. The anodic peak current $\left(\mathrm{i}_{\mathrm{p}: \mathrm{i}}\right)$ is almost equal to the cathodic peak current $\left(i_{p c}\right)$, as expected for a reversible couple. The one-electron nature of this oxidation has been confirmed by constant potential coulometric experiments (vide infra). The osmium(II)-osmium(III) oxidation potential in $\left[\mathrm{Os}(\mathrm{bpy})_{3}\right]^{2+}$ is $0.84 \mathrm{~V}$ [9]. In the $\left[\mathrm{Os}(\mathrm{bpy})_{2}(\mathrm{~L})\right]^{+} \mathrm{com}-$ plexes the same oxidation is taking place near $0.2 \mathrm{~V}$. The negative shift of oxidation potential observed upon replacing one bpy by one $L$ reflects the ability of these phenolate ligands to stabilize the +3 state of osmium. Similar systematic variation in redox potentials by stepwise substitution of pyridine ligands by phenolates in ruthenium complexes is well documented in literature [10]. This further points to the fact that inspite of coordination by the soft carbonyl oxygen, coordination by phenolate oxygen has been very effective in lowering the osmium(II)-osmium(III) oxidation potential. Comparison of the osmium(II)osmium(III) oxidation potential in [Os(bpy) $)_{2}($ sal $\left.)\right]^{*}$ $(0.25 \mathrm{~V})$ with the ruthenium(II)-ruthenium(III) oxjdation potential in $\left[\mathrm{Ru}(\mathrm{bpy})_{2}(\mathrm{sal})\right]^{+}(0.64 \mathrm{~V})^{\text {id }}$ shows that the oxidation is much easier in the osmium complexes. as expected.

A second oxidative response, irreversible in nature, is shown by $\left[\mathrm{Os}(\mathrm{bpy})_{2}(\mathrm{~L})\right] \mathrm{ClO}_{4}$ complexes in the range of $1.38-1.48 \mathrm{~V}$ but its assignment is unclear. The oneelectron nature of this oxidation is established by com-

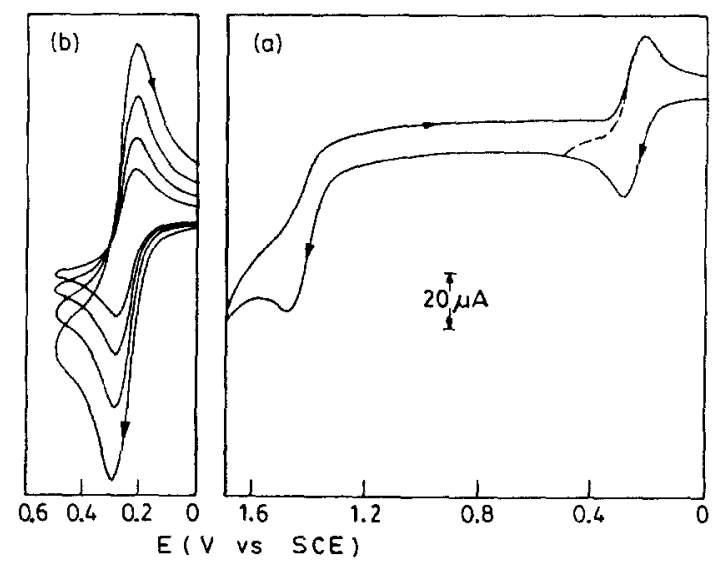

Fig. 3. Cyclic voltammograms of $\left[\mathrm{Os}(\mathrm{bpy})_{2}(\mathrm{sal})\right] \mathrm{ClO}_{4}$ in acetonitrile solution ( $0.1 \mathrm{M}$ TEAP) (a) at a scan rate of $50 \mathrm{mVs}$ and (b) at scan rates of $50,100,200$ and $400 \mathrm{mVs}$ ! 
paring its current height $\left(\mathrm{i}_{\mathrm{pa}}\right)$ with that of osmium(II)osmium(III) couple.

The three reductive responses, exhibited by the $\left[\mathrm{Os}(\mathrm{bpy})_{2}(\mathrm{~L})\right]^{+}$complexes on the negative side of SCE, are assigned to the reductions of the coordinated bpy ligands as shown in eqs (2)-(4).

$$
\begin{array}{r}
{\left[\mathrm{Os}^{\mathrm{II}}(\mathrm{bpy})_{2}(\mathrm{~L})\right]^{+}+\mathrm{e}^{-} \leftrightharpoons\left[\mathrm{Os}^{\mathrm{II}}(\mathrm{bpy})(\mathrm{b} \dot{\bar{p}} \mathrm{y})(\mathrm{L})\right]} \\
{\left[\mathrm{Os}{ }^{\mathrm{II}}(\mathrm{bpy})(\mathrm{b} \dot{\bar{p}} \mathrm{y})(\mathrm{L})\right]+\mathrm{e}^{-} \leftrightharpoons\left[\mathrm{Os}{ }^{\mathrm{II}}(\mathrm{b} \dot{\bar{p}} \mathrm{y})_{2}(\mathrm{~L})\right]^{-}} \\
{\left[\mathrm{Os}^{\mathrm{II}}(\mathrm{b} \dot{\bar{p}} \mathrm{y})_{2}(\mathrm{~L})\right]^{-}+\mathrm{e}^{-} \leftrightharpoons\left[\mathrm{Os}^{\mathrm{II}}(\mathrm{b} \dot{\bar{p} y})(b \overline{\bar{p}} \mathrm{y})(\mathrm{L})\right]^{2-}}
\end{array}
$$

It is well documented in the literature that each bpy ligand can successively accept two electrons in its lowest unoccupied molecular orbital [11]. Hence in these $\left[\mathrm{Os}(\mathrm{bpy})_{2}(\mathrm{~L})\right]^{+}$complexes four successive reductions may be expected, of which three have been experimentally observed. The fourth reduction could not be observed due to solvent cut-off.

\section{$\left[\mathrm{Os}^{\mathrm{III}}(\mathrm{bpy})_{2}(\mathrm{~L})\right]^{2+}$ complexes}

The reversible nature of the osmium(II)-osmium(III) oxidation in the $\left[\mathrm{Os}(\mathrm{bpy})_{2}(\mathrm{~L})\right]^{+}$complexes shows that the $\left[\mathrm{Os}{ }^{\mathrm{III}}(\mathrm{bpy})_{2}(\mathrm{~L})\right]^{2+}$ species are stable, at least on the cyclic voltammetric time scale. The oxidation potentials are relatively low, which further suggest that the oxidized complexes would be stable much longer time scale. To investigate the stability of the $\left[\mathrm{Os}^{\mathrm{III}}(\mathrm{bpy})_{2}(\mathrm{~L})\right]^{2+}$ complexes, they were electrochemically generated by coulometric oxidation of the $\left[\mathrm{Os}^{\mathrm{II}}(\mathrm{bpy})_{2}(\mathrm{~L})\right]^{+}$species at $0.5 \mathrm{~V}$. The oxidations were smooth and quantitative, resulting in a colour change of brown to green. The green solution of the $\left[\mathrm{Os}^{\mathrm{III}}(\mathrm{bpy})_{2}(\mathrm{~L})\right]^{2+}$ complexes shows identical cyclic voltammograms as their respective precursors, except that the osmium(II)-osmium(III) couple now appears as a reductive response. This indicates that no change in the coordination environment around osmium took place during oxidation. Coulometric reduction of the green solutions at $0.0 \mathrm{~V}$ gave back brown solutions of the respective $\left[\mathrm{Os}^{\mathrm{II}}(\mathrm{bpy})_{2}(\mathrm{~L})\right]^{+}$complexes, which were identified by their characteristic electronic spectra. Chemical oxidation of the $\left[\mathrm{O} s^{\mathrm{II}}(\mathrm{bpy})_{2}(\mathrm{~L})\right]^{+}$complexes by bromine in acetone solution also afforded the [Os"'(bpy $\left.)_{2}(\mathrm{~L})\right]^{2+}$ species, which were isolated as the perchlorate salt in the solid state. Characterization data of the $\left[\mathrm{Os}^{\mathrm{III}}(\mathrm{bpy})_{2}(\mathrm{~L})\right]\left(\mathrm{ClO}_{4}\right)_{2}$ complexes are given in Table 4. Composition of these complexes have been confirmed by their microanalitical data. Except small shift in band positions, the IR spectra of these oxidized complexes are almost identical to their respective $\left[\mathrm{Os}^{\mathrm{I}}{ }^{\mathrm{-}}\right.$ $\left.{ }^{\prime}(\text { bpy })_{2}(\mathrm{~L})\right]_{C l O}$ precursors. The $\left[\mathrm{Os}^{\mathrm{III}}(\mathrm{bpy})_{2}(\mathrm{~L})\right]$ $\left(\mathrm{ClO}_{4}\right)_{2}$ complexes are one-electron paramagnetic, which is in accordance with +3 state of osmium (lowspin $\left.d^{5}, S=1 / 2\right)$ in these complexes. However, ESR studies shows that these $\left[\mathrm{Os}^{\prime \prime \prime}(\mathrm{bpy})_{2}(\mathrm{~L})\right]\left(\mathrm{ClO}_{4}\right)_{2}$ complexes are ESR-silent. The ESR-inactivity in low-spin $\mathrm{d}^{5}$ complexes is known to result from extensive mixing of the Kramers doublets by strong spin-orbit coupling which gives rise to short electronic relaxation time [12]. In acetonitrile solution these $\left[\mathrm{Os}^{111}\right.$ (bpy) $\left.)_{2}(\mathrm{~L})\right]\left(\mathrm{ClO}_{4}\right)_{2}$ complexes behave as 1:2 electrolytes, as expected. Electronic spectra of the $\left[\mathrm{Os}^{111}\right.$ (bpy $\left.)_{2}(\mathrm{~L})\right]\left(\mathrm{ClO}_{4}\right)_{2}$ complexes have been recorded in acetonitrile solution. Each complex shows five absorptions, three intense ones in the visible region and two very intense ones in the UV region (Table 4, Fig. 2). The absorptions in the visible region are attributed to ligand-to-metal charge-transfer transitions and those in the UV region are assigned to transitions within the ligands orbitals. Chemical reduction of the green $\left[\mathrm{Os}^{\mathrm{III}}(\mathrm{bpy})_{2}(\mathrm{~L})\right]\left(\mathrm{ClO}_{4}\right)_{2}$ complexes in acetonitrile solution by hydrazine quantitatively affords the respective brown $\left[\mathrm{Os}^{\mathrm{II}}(\mathrm{bpy})_{2}(\mathrm{~L})\right] \mathrm{ClO}_{4}$ complexes. This shows that the osmium(II)-osmium(III) oxidation [eqn (1)] is

\begin{tabular}{|c|c|c|c|c|c|}
\hline \multirow[t]{2}{*}{ Compound } & \multicolumn{3}{|c|}{ Analytical data ${ }^{a}$} & \multirow{2}{*}{$\begin{array}{l}\mu_{\mathrm{eff}}^{\mathrm{b}} \\
\mu_{\mathrm{B}}\end{array}$} & \multirow{2}{*}{$\begin{array}{l}\text { Electronic spectral datac } \\
\lambda_{\max }, \mathrm{nm}\left(\epsilon, \mathrm{M}^{-1} \mathrm{~cm}^{-1}\right)\end{array}$} \\
\hline & $\% \mathrm{C}$ & $\% \mathrm{H}$ & $\% \mathrm{~N}$ & & \\
\hline$\left[\mathrm{Os}(\mathrm{bpy})_{2}(\mathrm{sal})\right]\left(\mathrm{ClO}_{4}\right)_{2}$ & $\begin{array}{c}39.48 \\
(39.42)\end{array}$ & $\begin{array}{c}2.60 \\
(2.55)\end{array}$ & $\begin{array}{c}6.80 \\
(6.81)\end{array}$ & 1.93 & $\begin{array}{l}614(2100), 452^{\mathrm{d}}(5700), 382(11200), \\
284(53000), 244(50400) .\end{array}$ \\
\hline$\left[\mathrm{Os}(\mathrm{bpy})_{2}(\mathrm{acp})\right]\left(\mathrm{ClO}_{4}\right)_{2}$ & $\begin{array}{l}40.20 \\
(40.19)\end{array}$ & $\begin{array}{c}2.77 \\
(2.75)\end{array}$ & $\begin{array}{c}6.68 \\
(6.70)\end{array}$ & 1.85 & $\begin{array}{l}594(1800), 470^{\mathrm{d}}(4000), 388(8300) \\
274(50200), 240^{\mathrm{d}}(37900)\end{array}$ \\
\hline$\left[\mathrm{Os}(\mathrm{bpy})_{2}(\mathrm{nap})\right]\left(\mathrm{ClO}_{4}\right)_{2}$ & $\begin{array}{c}42.71 \\
(42.66)\end{array}$ & $\begin{array}{c}2.63 \\
(2.64)\end{array}$ & $\begin{array}{c}6.44 \\
(6.42)\end{array}$ & 1.88 & $\begin{array}{l}648(1100), 442^{d}(5300), 387(10700), \\
291(37600), 237^{d}(43300) .\end{array}$ \\
\hline
\end{tabular}
chemically reversible as well.

Table 4. Characterization data of the $\left[\mathrm{Os}^{\mathrm{III}}(\mathrm{bpy})_{2}(\mathrm{~L})\right]\left(\mathrm{ClO}_{4}\right)_{2}$ Complexes.

"Calculated values are in parantheses.

${ }^{\mathrm{b}}$ In the solid state at $298 \mathrm{~K} ; \mu_{\mathrm{B}} \sim 9.27402 \times 10^{-24} \mathrm{JT}^{-1}$.

'In dichloromethane solution.

¿Shoulder. 


\section{CONCLUSION}

The present study on the $\left[\mathrm{Os}(\text { bpy })_{2}(\mathrm{~L})\right] \mathrm{ClO}_{4} \mathrm{com}-$ plexes reveals that coordination by phenolate oxygen is very effective in stabilizing the higher oxidation states of osmium. The observed shift in osmium(II)osmium(III) oxidation potential in going from $\left[\mathrm{Os}(\mathrm{bpy})_{3}\right]^{2+}(0.84 \mathrm{~V})$ to $\left[\mathrm{Os}(\mathrm{bpy})_{2}(\mathrm{sal})\right]^{+}(0.25 \mathrm{~V})$ indicates that in the osmium complexes having more of these phenolate ligands, this oxidation will be much easier. For example, in the $\left[\mathrm{Os}(\mathrm{bpy})(\mathrm{sal})_{2}\right]^{\mathrm{n}+}$ and $\left[\mathrm{Os}(\mathrm{sal})_{3}\right]^{\mathrm{m}+}$ complexes, the same osmium(II)osmium(III) oxidation may be expected to appear near $-0.3 \mathrm{~V}$ and $-0.9 \mathrm{~V}$ respectively. Therefore the air-stable oxidation state of osmium in these two complexes will be +3 or higher. Studies on these two and other osmium-phenolate complexes are currently in progress.

Acknowledgements--Financial assistance received from the Council of Scientific and Industrial Research. New Delhi [Grant No. 01(1408)/96/EMR-II] is gratefully acknow]edged. Thanks are also due to the Third World Academy of Sciences for financial support for the purchase of an electrochemical cell system. The authors thank Dr. Sreebrata Goswami of Indian Association for the Cultivation of Science. Calcutta, and Dr. Rupendranath Banerjee of Jadavpur University, Calcutta, for their help. FB thanks the University Grants Commission, New Delhi, for her fellowship.

\section{REFERENCES}

1. (a) Seddon, K. R., Coord. Chem. Rev., 1982, 41, 159; (b) Moore, D. S.. Coord. Chem. Ret., 1982. 44, 127; (c) Gulliver, D. J. and Levason, W., Coord. Chem. Ret., 1982, 46, 1; (d) Seddon. E. A., Coord. Chem. Ret., 1985, 67, 243. (e) Albers, M. O., Robinson, D. J. and Singleton, E., Coord. Chem. Rer.. 1987, 79, 1; (f) Thomas, N. C., Coord. Chem. Rev., 1989, 93, 225; (g) Rong, D., Hong, H. G., Kim, Y. I., Krueger, J. S., Mayer, J. E. and Mallouk, T. E., Coord. Chem. Ret., 1990, 97, 237; (h) Yam, V. W. W. and Che, C. M., Coord. Chem. Rev., 1990. 97, 93; (i) Hage, R., Coord. Chem. Ret., 1991, 111, 161; (j) Collin, J. P., Guillerez, S., Sauvage, J. P., Barigelletti, F., Flamigni, L. Cola, L. D. and Balzani, V., Coord. Chem. Rer., 1991, 111, 291; (k) Cola, L. D., Barigelletti. F., Balzani, V., Belser, P., Zelewsky, A. V., Seel. C., Frank, M. and Vogtle, F., Coord. Chem. Ret.. 1991, 111, 255; (1) Constable, E. C. and Housecroft, C. E., Coord. Chem. Rer., 1993, 124, 183; (m) Ward, M.D.. Coord. Chem. Rev.. 1993, 127, 1: (n) Furue. M.. Maruyama, K., Kanematsu,
Y.. Kushida, T. and Kamachi, M., Coord. Chem. Rer., 1994, 132, 201; (o) Collin, J. P., Sauvage, J. P., Sour, A.. Constable, E. C. and Thompson, A. M. W. C. Coord Chem. Rer., 1994, 132, 209; (p) Kalyansundaram, K., Zakeeruddin, S. M. and Nazeeruddin, M. K., Coord. Chem. Rer.. 1994. 132, 259; (q) Richmond, M. G., Coord. Chem. Rer., 1995, 141, 63; (r) Ward, M. D.. Coord. Chem. Rev. 1995, 146, 99.

2. (a) Hursthouse, M. B.. Fram, T.. New, L.. Griffith, W. P. and Nielson, A.. Trunsition Met. Chem. 1973, 3, 255; (b) Nielson. A and Griffith, W. P., J. Chem. Soc., Dalton Trans.. 1978, 1501: (c) Lahiri, G. K.. Bhattacharya, S., Ghosh, B. K. and Chakravorty, A., Inorg. Chem., 1987, 26, 4324; (d) Haga, M.. Isobe, K.. Boone, S. R. and Pierpont, C.G., Inorg. Chem.. 1990, 29, 3795: (e) Bhattacharya, S.. Boone, S. R.. Fox, G. A. and Pierpont. C. G., J. Am. Chem. Soc.. 1990. 112, 1088: (f) Bhattacharya, S. and Pierpont. C. G.. Inorg. Chem.. 1991, 30, 2906: (g) Bhattacharya, S. and Pierpont. C. G., Inorg. Chem., 1992. 31, 35.

3. (a) Gopinathan, S., Joseph, K. and Gopinathan, C.. Indian J. Chem., 1987, 26A, 128; (b) Joseph, K.. Despande, S. S., Pardhy, S. A.. Unny, I. R., Pandit, S. K., Gopinathan. S. and Gopinathan, C.. Inorg. Chim. Acta1984, 82(1). 59; (c) Gopinathan. S. Pardhy, S. A. and Gopinathan. C.. Sinth. React. Inorg. Met.-Org. Chem.. 1986. 16, 475; (d) Bag. N.. Lahiri. G. K.. Bhattacharya. S., Falvello, L. R. and Chakravorty. A.. Inorg. Chem., 1988, 27, 4396; (e) Chakravarty, J. and Bhattacharya. S., Polyhedron. 1996, 15, 257.

4. Dwyer, F. P. and Hogarth, J. W.. Inorg. Sinth.. $1957,5,204$

5. Kober, E. M., Casper, J. V. Sullivan. B. P. and Meyer, T. J., Inorg. Chem., 1988, 27, 4587.

6. Sawyer, D. T. and Roberts Jr.. J. L. Experimental Electrochemistry for Chemists. John Wiley. New York. 1974. pp. 167-215.

7. Walter. M. and Ramaley, L.. Anal. ('hem.. 1973. 45,165

8. (a) Pankuch, B. J., Lacky, D. E. and Crosby, G A., J. Phis. Chem. 1980, 84, 2061: (b) Ceulemans, A., Vanquickenborne, L. G.. J. Am. (hem. Soc.. 1981, 103, 2238: (c) Decurtis, S., Felix. F.. Ferguson. J., Gudel. H. U. and Ludi, A., J. Am. Chem. Soc., 1980, 102, 4102; (d) Kober. E. M. and Meyer, T. J.. Inorg. Chem., 1982, 21, 3967.

9. This oxidation potential has been determined by us.

10. Bardwell, D. A.. Black, D., Jeffery, J. C.. Schatz, E. and Ward. M. D., J. Chem. Soc., Dalton Trams. 1993.2321.

11. (a) Vlcek, A. A.. Coord. Chem. Rer., 1982, 43, 39; (b) Kahl, J. L., Hanck, K. W. and DeArmond, K., J. Phys. Chem., 1978, 82, 540.

12. Shirin. Z. and Mukherjee. R. N., Polyedron. $1992,11,2625$. 